\title{
Use of the Solid Waste Management Strategies Adopted by Manufacturing Companies in Beni, Democratic Republic of Congo
}

\author{
Sifa Kpaka Jolie \\ Economics Sciences and Management Department, Congo Initiative, Université Chrétienne Bilingue du Congo, North Kivu, Beni, \\ Democratic Republic of Congo \\ Email: joliesifa5@gmail.com
}

How to cite this paper: Jolie, S.K. (2021) Use of the Solid Waste Management Strategies Adopted by Manufacturing Companies in Beni, Democratic Republic of Congo. Open Access Library Journal, 8: e8313. https://doi.org/10.4236/oalib.1108313

Received: December 21, 2021

Accepted: January 25, 2022

Published: January 28, 2022

Copyright $\odot 2021$ by author(s) and Open Access Library Inc.

This work is licensed under the Creative Commons Attribution International License (CC BY 4.0).

http://creativecommons.org/licenses/by/4.0/ (c) (i) Open Access

\begin{abstract}
Better inventory and material handling could lead to reduction of raw material solid waste. Reducing waste under inventory control entails purchasing only the amount of raw materials needed for a production run or a set period of time, purchasing the material in the proper amount and the proper size container, approaching the suppliers to see if they can take back the excess materials, and developing review procedures for all materials purchased, to minimize the chances of storing them beyond their shelf-life period. Improving the efficiency of a production process can significantly reduce process waste generation. It can be achieved or enhanced through medication in operational and maintenance procedures, material change and equipment. There are various solid waste management strategies manufacturing companies have adopted to enhance sustainability. However, from this study's findings, $69.44 \%$ of the employees of the manufacturing companies in Beni City generally agreed that reduction strategy had been adopted, $53 \%$ also generally agreed that re-use strategy had been adopted, and that recycling is being carried in their respective companies as a solid waste management strategy at $55.88 \%$. In addition to these study findings, proper control over raw materials, intermediate products, final products, and the associated waste streams are an important waste reduction strategy.
\end{abstract}

\section{Subject Areas}

General Management, Managerial Economics, Operations Management

\section{Keywords}

Solid Waste, Management, Strategies, Manufacturing Companies, Beni 


\section{Introduction}

According to Hariz and Bahmed (2013) [1], waste management strategy is a plan or policy to achieve a major or overall aim of managing waste from its inception to its final disposal. Solid waste management strategies are applied alongside the waste management hierarchy. The hierarchy includes prevention, reduction, recycling, recovery and disposal (Fernández, J. M. M., Palacios, H. M., \& Cabal, J. V. Á., 2015) [2]. Waste prevention requires that the range, composition and design of products be changed in order to reduce waste through reduced resource demand and/or improved quality, in other words, improved manageability or reduced use of hazardous materials. The prevention of waste can be done at source separation, the successful re-use, composting, anaerobic digestion and recycling are paramount by separating out goods and materials from the waste stream at source, are paramount for successful re-use, composting, anaerobic digestion, and recycling (UNEP, 2013) [3]. Separation at source has two main benefits: it enables the value of re-usable goods and recyclable materials to be recovered efficiently; and the composition is less mixed and therefore less in need of sorting, reducing the problems of dealing with waste downstream, where sorting is more difficult and expensive. Recycling requires that materials be collected, sorted, processed, and converted into useful goods (Hariz, S., \& Bahmed, L., 2013) [1]. Sometimes the products of recycling are similar to the products from which they were originally derived, such as recovered office paper reprocessed into stationery. At other times, the products are very different, such as recovered plastic packaging converted into fleece sweaters, or the example of valuable metals, including gold, silver, palladium, copper and tin, being recovered from e-waste and sold to smelters for refining and reuse.

Materials recovery involves the dismantling and sorting of discarded products to separate out useful materials, and where appropriate to clean them and ready them for reuse such as the example of the treatment and dismantling of end-of-life vehicles to obtain tires, glass, plastics, metals and other reusable or recyclable materials. Energy recovery from waste is regarded as preferable to waste disposal without energy recovery. Conventional or oxidative combustion or incineration with energy recovery is a widely applied technology (UNEP, 2013) [3]. Disposal is the management option used for the remaining fraction of waste when all forms of diversion, reuse and valorization are exhausted (Mallak, S. K., Elfghi, F. M., Rajagopal, P., Vaezzadeh, V., \& Fallah, M., 2016) [4]. It also has the important function of removing unwanted materials from the life-cycle for a final safe and secure storage.

\subsection{Manufacturing Companies in Beni, Democratic Republic of Congo}

Beni is a city of North Kivu Province, in north eastern Democratic Republic of Congo, lying immediately west of the Virunga National Park and the Rwenzori Mountains, on the edge of the Ituri Forest. As of 2013 it had an estimated popu- 
lation of 231,952 (UN-OCHA, 2013) [5]. Beni contains four communes, or municipalities; Beu, Bungulu, Rwenzori and Mulekera. The DRC's small industrial base is dominated by manufacturing and food processing, both of which have been in steep decline due to years of mismanagement, lack of investment, and the population's growing dependence on various informal artisanal activities to make ends meet (Mpinda, M. T., Abass, O. K., Bazirake, M. B., Nsokimieno, E. M. M., Mylor, N. S., Kayembe, K. W. M., Khonde, R., 2016) [6]. The key obstacles to a more diversified and sustainable industrial development are a weak supportive regulatory environment, poor enforcement capacity, energy constraints and limited access to credit. Deteriorating infrastructure and subsequent geographical isolation as well as increased insecurity have led to the decline of many agro-industries at the provincial level.

\subsection{Solid Waste Management Strategies within Manufacturing Companies in Beni}

Production and consumption of products has been on the rise hence materials ending up in waste streams have enormously increased in amount. In developed countries, authorities and societies are particularly keen on good environmental management thus, there is a lot of effort put in place to have corresponding measures to counter the situation of increasing waste volumes (Kubanza, N. S., \& Simatele, D., 2016) [7]. However, in developing countries like Democratic Republic of the Congo and specifically in Beni City within the manufacturing sector, effective solid waste management remains a big challenge. Even with all the advancements that societies have been through, solid waste management systems that were designed for a small simple society remain more or less the same and can no longer cope with today's complicated situations (Ndum, 2013) [8]. Solid waste management is yet to be given the attention it deserves, meanwhile, waste materials continue to degrade the environment and affect the health of the people. Weak land use planning and enforcement have allowed people to settle in an ad-hoc manner in designated industrial areas, and likewise for manufacturing facilities to be in residential and inappropriate locations as observed in Beni's manufacturing area. Due to limited formal controls and monitoring, untreated manufacturing effluent and solid waste is commonly disposed of directly into the environment, leading to a high risk of ecosystem contamination in certain areas.

\section{Literature Review}

\subsection{Waste Reduction Strategies in Manufacturing Companies}

Waste reduction is essential for every industry that manufactures products and incurs a cost. Factories, mills, and mining operations are among the industries that produce more waste. Earth's natural resources are continuously depleting, and this is one of the major environmental problems today. Industrial waste and emissions can have drastic effects both financially and environmentally, and in 
some developing countries, the amount of waste created by manufacturers is so alarming that businesses are tasked to come up with new ways for waste reduction (Chowdhury, A. H., Mohammad, N., Ul Haque, R., \& Hossain, T., 2014) [9]. Waste reduction can result in profit maximization and efficiency. Waste reduction is now a concern for businesses, and thousands of manufacturers are creating waste reduction policies and strategies (Yousuf, T. B., \& Reza, A., 2013) [10]. However, only a few businesses understand the cost that waste can have on their bottom-line. Waste reduction is a tool that can be used to create a better business environment in industries.

Proper control over raw materials, intermediate products, final products, and the associated waste streams is an important waste reduction technique (Chowdhury, A. H., Mohammad, N., Ul Haque, R., \& Hossain, T., 2014) [9]. Better inventory and material handling could lead to reduction of raw material waste. Reducing waste under inventory control entails purchasing only the amount of raw materials needed for a production run or a set period of time, purchasing the material in the proper amount and the proper size container, approaching the suppliers to see if they can take back the excess materials, and developing review procedures for all materials purchased, to minimize the chances of storing them beyond their shelf-life period.

Material handling entails ensuring that raw materials reach the production process without loss through contamination, spills, and leaks; ensuring that the material is efficiently handled and used in the production process and does not become waste; handling waste or rejects like a product, allowing a recyclable or clean waste material to be contaminated to reduce or eliminate its recovery potential; encouraging employees to separate waste that can be recycled from those that have to be sent for incineration or landfill, labelling and placing recycling and trash bins in strategic locations of production process areas.

Chowdhury, et al. (2014) [9] argues that improving the efficiency of a production process can significantly reduce process waste generation. It can be achieved or enhanced through medication in operational and maintenance procedures, material change and equipment. Operational and maintenance procedures entails looking for opportunities to further improve efficiency of operational process procedures, most production processes can be operated more efficiently, no matter how long they have been in operation or how well they have been run, some process steps may in fact be unnecessary and eliminating them will reduce waste generation; documenting fully improved operating procedures, and make them part of the regular employee training program; implementing a strict maintenance program, which stresses preventive and corrective maintenance, to reduce waste generation caused by equipment failure, such a program can help spot potential sources of release and correct a problem before any material is lost; and maintaining a strict schedule on all maintenance activities under the program and keep accurate records. Material change entails considering material change that will lead to the elimination of one step of the process, this could lead 
to elimination or reduction of raw material used and waste generated, and improve the process efficiency; considering material change that may have an impact on overall waste reduction; using a less hazardous material in a production process where possible; looking for ways to avoid contamination of a waste so that it can be put back into the originating process as a substitute for a raw material; looking for ways to use a waste as a raw material in another process. Process equipment modification encompasses modifying existing or install more efficient process equipment to take advantage of better production technologies, new or updated equipment can usually process materials more efficiently, reduce the amount of raw material used, and cut down the number of off-specification products or rejects, this will reduce waste and costs. In many cases, improved operational procedures and process equipment modifications are used together to improve efficiency, and reduce costs and waste.

Waste reduction can also touch the reduction of packaging waste. The packaging materials usually include cardboard, plastics, and drums. Packaging waste will be either from suppliers, who deliver the materials needed for production, or in the form of packaging material used to pack and ship products to customers (Yousuf, T. B., \& Reza, A., 2013) [10]. Using packaging materials more than necessary to pack and ship products costs more in purchasing, materials handling, and shipping. This also generates more packaging waste at customers' end. If suppliers use packaging materials more than necessary to supply the goods, or use single-use packaging, it generates more waste at the facility, costs more time to handle, and incurs more disposal cost if the packaging is not recyclable.

Waste reduction entails reduction of office waste too. In a typical office, usually half of the total waste is paper-based. Paper is therefore a major purchasing and disposal coast to the average office. Yet it is a cost that can be brought down easily through reduction, reuse and recycling.

Reduction of office waste can be effective by making it a company policy that all printing, photocopying and publications are produced in double-sides format where possible; putting reminder posters near printers and photocopiers; cancelling subscriptions of unwanted publications to reduce paper waste; avoiding overproduction of marketing and publicity material by reviewing distribution lists and regularly updating databases; using electronic communication where possible to reduce printing and fixing, ensuring that staff is comfortable with new technology and provide training where necessary, encouraging them not to print out e-mails unless absolutely necessary; eliminating the use of fax cover sheet where possible; ensuring fax machines are set so that they do not produce unwanted headers or report sheets; reducing confidential waste costs by giving clear instructions to staff as to which material is strictly confidential, and which is general paper waste; using single-spacing for report or memo writing; setting narrower margins for drafts; changing margins to avoid the last page of report with little text; editing and proof-reading carefully on the computer before printing; and sharing newspapers or magazines. 


\subsection{Waste Reuse Strategies in Manufacturing Companies}

Reuse is the action or practice of using something again, whether for its original purpose (conventional reuse) or to fulfil a different function (creative reuse or repurposing) (Chowdhury, A. H., Mohammad, N., Ul Haque, R., \& Hossain, T., 2014) [9]. It should be distinguished from recycling, which is the breaking down of used items to make raw materials for the manufacture of new products. Fernández et al. (2015) [2] argues that reuse by taking, but not reprocessing, previously used items helps save time, money, energy and resources. Many products are designed to be used more than once. Reusable products and containers often result in less waste. This helps reduce the cost of managing solid waste and often conserves materials and resources. If maintained and repaired properly, products such as long-wearing clothing, tires, and appliances are less likely to wear out or break and will not have to be thrown out and replaced as frequently.

Although durable products sometimes cost more initially, their extended life span may offset the higher cost and even save money over the long term. Many everyday items can have more than one use (Yousuf, T. B., \& Reza, A., 2013) [10]. Before discarding bags, containers, and other items, consider if it is hygienic and practical to reuse them. Reusing products extends their lives, keeping them out of the solid waste stream longer. Adopt the ideas that work, add some more, and then challenges others in school, office, and community to try these ideas and to come up with others. Seldom-used items, like certain power tools and party goods, often collect dust, rust, take up valuable storage space, and ultimately end up in the trash. Renting or borrowing these items the next time they are needed. Infrequently used items also might be shared among neighbors, friends, or family. Borrowing, renting, or sharing items saves both money and natural resources. It is important to collect all paper that has been printed on one side and reuse it for printing in draft or for scrap message pads; to reuse envelopes wherever possible, especially for sending information internally; and to reuse paper file folders.

Another effective way to reuse solid waste is through burning materials that are combustible. Additionally, non-combustible materials can be melted down at the company's incinerators. The resulting residue after such incineration can be dumped in landfills. Combustion can be defined as the burning of waste in a controlled environment in a bid to reduce waste volumes that are sent to landfills. This process can also generate electricity. This technique is effective especially where wastes cannot be recycled and are generated in large quantities. Key to note is that the waste combustion process can lead to the emission of toxic air emissions, but they can be controlled through the installation of control equipment for instance fabric filters and acid gas scrubbers and in waste combustors (UNEP, 2013) [3]. In addition, research carried out in the United States of America also indicates that $13 \%$ of the Municipal Solid Waste produced are not just used to burn trash however the heat generated is used to generate electricity 
(Wong, J. W. C., Surampalli, R. Y., Zhang, T. C., Tyagi, R. D., \& Selvam, A., 2016) [11].

\subsection{Waste Recycling Strategies in Manufacturing Companies}

Recycling is a resource recovery practice that refers to the collection and reuse of waste materials such as empty beverage containers. The materials from which the items are made can be reprocessed into new products. Material for recycling may be collected separately from general waste using dedicated bins and collection vehicles (Conrad, 2000) [12]. Recoverable materials that are organic in nature, such as plant material, food scraps, and paper products, can be recovered through composting and digestion processes to decompose the organic matter. The resulting organic material is then recycled as mulch or compost for agricultural or landscaping purposes. Conrad (2000) [12] states that energy recovery from waste is the conversion of non-recyclable waste materials into heat, electricity, or fuel through a variety of processes, including combustion, gasification, pyrolyzation, anaerobic, and landfill gas recovery. This process is often called waste-to-energy.

Energy recovery from waste is part of the non-hazardous waste management hierarchy and can reduce carbon emissions by offsetting the need for energy from fossil sources as well as reduce methane generation from landfills. Resource recovery is the systematic diversion of waste, which was intended for disposal, for a specific next use (Ascher, 2000) [13]. It is the processing of recyclables to extract or recover materials and resources, or convert to energy. These activities are performed at a resource recovery facility. Resource recovery is not only environmentally important, but it is also cost-effective. It decreases the amount of waste for disposal, saves space in landfills, and conserves natural resources. Resource recovery uses Life Cycle Assessment.

Set up a waste paper collection system and send waste paper for recycling. Place paper recycling bins in all office areas. A good guide is one bin between six staff members, and one next to each photocopier and printer. Use paper ream lids as additional staff desk top collection trays. Ensure that cleaning staff are in support of the recycling scheme and that emptying the recycling bins is part of their contracted work. Promote the scheme to staff by putting up posters around the offices, and on bins explaining the types of paper that can be recycled. Provide staff with on-going feedback about the schemes, including figures on the amount of paper collected. Suggest making a donation to charity or planting a tree when targets are met. Paper is a natural resource that can be recycled up to about five times. This substantially reduces the impact on the environment. By using recycled paper, the market for recycled products will be boosted. This will in turn support the recycling industry and reduce unnecessary use of virgin materials.

Recycle unlike reuse is the process of using materials to make new products. Recycling is mostly carried out by companies at waste recycling plants. The old 
used materials are taken through a process that will yield new products (Yousuf, T. B., \& Reza, A., 2013) [10]. In my opinion recycling means taking a material and subjecting it to other processes that will entirely change the raw materials and put it in a totally different form. Mostly this is the final strategy of waste management. Hosoda (2014) [14] explains that recycling is obtaining waste elements and taking them through a process that will eventually yield a totally new item. Sustainability needs companies to think of new and better ways of producing and consuming goods and services. industries are tasked with the responsibility of providing goods and services that reduce negative environmental and social impact all through the product life cycles from design, production, consumption and ultimate disposal (UNEP, 2013) [3].

\subsection{Waste Management Corporate Policies}

A growing number of national and international law now regulates the manner in which wastes are disposed of. These legislative constraints are enforced by social, fiscal and commercial pressures (UNEP, 2013) [3]. This environmental legislation is making the reduction and management of waste streams an important issue even for organizations in the supply chain such as wholesalers and retailers, who merely pass through materials that will ultimately become waste. Waste management has become a complex area, legally, technically and commercially. Very few organizations can still rely on the waste collection services provided through local authorities as a complete answer to their waste management obligations. Thus many firms need to identify and contracts one or more reputable, licensed, specialist companies for the disposal of their waste, or discharging their legal obligations.

\section{Methodology}

Coopers and Schindler (2008) [15] define a sampling technique as the method used to pick out a representative portion from which to carry out a test from the population. The sampling technique that was used was stratified probability sampling technique where the study grouped the population into different strata on the basis of employees among the selected companies. The strata represented different companies. A stratified sampling is a probability sampling design that first divides the population into meaningful non overlapping subsets, and then randomly chooses the subjects from each subset (Mugenda, O., \& Mugenda, A., 2003) [16]. The essence of stratification is to ensure inclusion, in the sample, of subgroup, which otherwise would be omitted entirely by other sampling methods because of their small numbers in the population (Neuman, 2014) [17]. The study used the proportionate stratified random sampling formula presented by Mugenda and Mugenda (2003) [16] as:

$$
n h=(N h / N) \times n
$$

where $n h$ is the sample size for strata $h, N h$ is the population size for strata $h, N$ is the total population size, and $\mathrm{n}$ is the total sample size. For instance, in Bra- 
simba: $N$, the population size for Basimba is $82 ; N$, the total population is 506 ; $n$, the total sample size is 152 ; the $n h$, sample size for Brasimba was then equal to $(82 / 506) \times 152=25$ respondents (Table 1$)$.

Respondents in each stratum were then obtained using simple random sampling as a probability sampling by generating random numbers representing target population in each stratum where sample numbers was randomly picked from. This is a design in which every element in the population has a known and equal chance of being selected as a subject (Hay, 2016) [18]. Sekaran and Bougie (2016) [19] confirm that a simple random sampling is probabilistic and is also known as chance sampling. Simple random sampling is easy to implements and every unit has an equal chance of being selected and hence eliminating selection biasness.

\section{Analysis and Findings}

\subsection{Relationship between Level of Education, Age and Marital Status}

The researcher sought to know whether there is a connection between level of education, age bracket and marital status. Therefore, cross-tabulation analysis between the three variables was conducted and the results are as shown in Table 2.

The findings in Table 2 show that out of the three respondents who had primary education only, one of them was single and 49 - 58 years old, while two were widows and above 59 years old. Out of the 46 respondents who had secondary

Table 1. Sample matrix.

\begin{tabular}{cccc}
\hline Company & Municipality & Target Population & Sample \\
\hline Brasimba & Bungulu & 82 & 25 \\
Okapi Group & Ruwenzori & 44 & 13 \\
Kal-Manga & Beu & 14 & 4 \\
Esco-Kivu & Bungulu & 51 & 15 \\
NRA & Mulekera & 92 & 28 \\
Sicovir & Ruwenzori & 49 & 15 \\
Copac & Ruwenzori & 32 & 10 \\
Maison La Neige & Mulekera & 15 & 4 \\
Maison Salama & Mulekera & 46 & 14 \\
SCAK & Ruwenzori & 38 & 11 \\
Autrionfale & Beu & 16 & 5 \\
Urgence Express & Mulekera & 12 & 4 \\
Maison des Ingenieurs & Bungulu & 15 & 4 \\
Total & & 506 & 152 \\
\hline
\end{tabular}

Source: The researcher (2018). 
Table 2. Cross tabulation for the level of education, age and marital status.

\begin{tabular}{|c|c|c|c|c|c|c|}
\hline \multirow[b]{2}{*}{ Marital Status } & \multirow[b]{2}{*}{ Age bracket } & \multicolumn{5}{|c|}{ Level of education } \\
\hline & & $\begin{array}{c}\text { Primary } \\
\text { school }\end{array}$ & $\begin{array}{c}\text { Secondary } \\
\text { school }\end{array}$ & Graduate & Post-graduate & Total \\
\hline \multirow{6}{*}{ Married } & $18-28$ & & 4 & 32 & 0 & 36 \\
\hline & $29-38$ & & 8 & 14 & 2 & 24 \\
\hline & $39-48$ & & 3 & 9 & 0 & 12 \\
\hline & $49-58$ & & 2 & 0 & 0 & 2 \\
\hline & Above 59 & & 2 & 2 & 0 & 4 \\
\hline & Total & & 19 & 57 & 2 & 78 \\
\hline \multirow{5}{*}{ Single } & $18-28$ & 0 & 11 & 15 & 0 & 26 \\
\hline & $29-38$ & 0 & 14 & 8 & 1 & 23 \\
\hline & $39-48$ & 0 & 2 & 0 & 7 & 9 \\
\hline & $49-58$ & 1 & 0 & 0 & 1 & 2 \\
\hline & Total & 1 & 27 & 23 & 9 & 60 \\
\hline \multirow{2}{*}{ Widow } & Above 59 & 2 & & & & 2 \\
\hline & Total & 2 & & & & 2 \\
\hline \multirow{6}{*}{ Total } & $18-28$ & 0 & 15 & 47 & 0 & 62 \\
\hline & $29-38$ & 0 & 22 & 22 & 3 & 47 \\
\hline & $39-48$ & 0 & 5 & 9 & 7 & 21 \\
\hline & $49-58$ & 1 & 2 & 0 & 1 & 4 \\
\hline & Above 59 & 2 & 2 & 2 & 0 & 6 \\
\hline & Total & 3 & 46 & 80 & 11 & 140 \\
\hline
\end{tabular}

education, 19 of them were married whereby four were $18-28$ years, eight were 29 - 38 years, three were 39 - 48 years, two were 49 - 58 years and two were above 59 years. The remaining 27 with secondary education were single whereby 11 were 18 - 28 years, 14 were 29 - 28 years and two were $39-48$ years. Out of the 80 respondents who indicated that they had obtained education up to University level, 57 of them were married whereby 32 were $18-28$ years old, 14 were 29 - 38 years old, 9 were 39 - 48 years old and two were above 59 years old. The other 23 respondents with university education were single whereby 15 of them were 18 - 28 years old while eight were 29 - 38 years old. Out of the 11 respondents who had obtained education up to post-graduate level two were married and were $29-38$ years old while the remaining nine were single whereby one was 29 - 38 years old, seven were 39 - 48 years, and one was 49 - 58 years old.

\subsection{Department of Work}

The study sought to know the department in which the respondents worked for in their respective manufacturing companies in Beni City, DRC. Findings are as 
presented in Table 3.

Findings in Table 3 show that five departments were represented in this study with $61(43.6 \%)$ of the respondents working for Production Department, 28 (20.0\%) worked for Finance Department, 19 (13.6\%) worked for Marketing Department, 17 (12.1\%) worked in the Strategy and Operations Department, while 13 (9.3\%) worked for Human Resource Department. Two (1.4\%) did not indicate the department in which they worked for. Therefore, the findings of this study were obtained from different departments of manufacturing companies thus diversified opinions and views on the effectiveness of solid waste management strategies adopted by the manufacturing companies. According to Choi (2016) [20], it is important that the population covered under a study represent the major areas of operations in the organization.

\subsection{Period Employees Had Worked in Their Respective Companies}

Last but not least on demographic information, the researcher sought to know the period respondents had worked with their respective manufacturing companies to establish their experience with solid waste management strategies that their companies had adopted. The findings are presented in Table 4.

Table 3. Department employees were working for in their respective companies.

\begin{tabular}{ccc}
\hline Department of Work & Frequency & Percentage (\%) \\
\hline Production & 61 & 43.6 \\
Finance & 28 & 20.0 \\
Marketing & 19 & 13.6 \\
Strategy and Operations & 17 & 12.1 \\
HRM & 13 & 9.3 \\
No Response & 2 & 1.4 \\
Total & 140 & 100 \\
\hline
\end{tabular}

Table 4. Period employees had worked in their respective companies.

\begin{tabular}{ccc}
\hline Number of years worked & Frequency & Percentage (\%) \\
\hline Less than 1 Year & 44 & 31.4 \\
1 - 5 years & 74 & 52.9 \\
6 - 10 years & 11 & 7.9 \\
$11-15$ years & 3 & 2.1 \\
16 - 20 years & 3 & 2.1 \\
21 and above years & 4 & 2.9 \\
No response & 1 & .7 \\
Total & 140 & 100.0 \\
\hline
\end{tabular}


Findings in Table 4 show that slightly more than half at 74 (52.9\%) of the employees of the manufacturing companies in Beni City had worked with their respective companies for 1 - 5 years, 44 (31.4\%) had worked for less than one year, while $11(7.9 \%)$ had worked for 6 - 10 years. Only a few of the employees of the manufacturing companies in Beni City had worked in the manufacturing sector for more than 10 years as shown in the table. According to Choi (2016) [20], the period the employees have working in a company helps to understand the experience of respondents in their work station making them the best candidates for the study. Based on these findings, it is evident that quite a number of respondents had experience with manufacturing companies and probably had experience with solid waste management strategies adopted by the companies and their effectiveness in organizational sustainability.

\subsection{Solid Waste Management Strategies Adopted by Manufacturing Companies}

The objective of this study was to establish solid waste management strategies adopted by the manufacturing companies. The researcher focused on three strategies which include reduction, re-use, and recycling. The study findings on the three strategies were as discussed here in after.

\subsection{Solid Waste Management Reduction Strategy}

The researcher sought to know the extent to which manufacturing companies in Beni City had adopted the reduction strategy in managing their solid wastes. To achieve this, the researcher listed general statements with regards to reduction strategy and asked the respondents to the extent to which they agreed or disagreed to those statements. The Findings are as shown in Table 5.

From the findings in Table 5, employees of the manufacturing companies agreed and strongly agreed that a sustainable method of waste management involves looking for opportunities to reduce solid waste even during the product life cycle at $110(78.6 \%)$ while $17(12.1 \%)$ were neutral, $11(7.8 \%)$ disagreed and strongly disagreed, and $2(1.4 \%)$ did not respond on the same; they also strongly agreed and agreed that having proper solid waste reduction systems that are included in company policies and procedures facilitates organizational sustainability at $105(75.0 \%)$ while $20(14.3 \%)$ were neutral, 7 (5\%) disagreed, and 8 (5.7\%) did not respond on the same; and they strongly agreed and agreed that waste reduction is now a concern for business, manufacturers should create waste reduction policies and strategies at $103(73.6 \%)$ while 21 (15\%) were neutral, 9 (6.4\%) disagreed, and 7 (5\%) did not respond on the same. Further, 79 (56.4\%) of the employees agreed and strongly agreed that having a tax policy that ensures companies are taxed based on the amount of waste they produce can help facilitate organizational sustainability while 41 (29.3\%) were neutral, 16 (11.5\%) disagreed and strongly disagreed, and $4(2.9 \%)$ did not respond on the same. 89 $(63.6 \%)$ agreed' and "strongly agreed" that waste reduction can result in profit maximization and efficiency while 38 (27.1\%) were neutral, 9 (6.5\%) disagreed 
Table 5. Solid waste management reduction strategy practices adopted by manufacturing companies.

\begin{tabular}{|c|c|c|c|c|c|c|c|c|}
\hline \multicolumn{2}{|l|}{ Reduction strategy practices } & SA & A & $\mathrm{N}$ & $\mathrm{D}$ & $\mathrm{SD}$ & NR & Total \\
\hline $\begin{array}{l}\text { A sustainable method of waste } \\
\text { management involves looking for }\end{array}$ & $\mathrm{N}$ & 39 & 71 & 17 & 9 & 2 & 2 & 140 \\
\hline $\begin{array}{l}\text { opportunities to reduce solid waste } \\
\text { even during the product life cycle }\end{array}$ & $\%$ & 27.9 & 50.7 & 12.1 & 6.4 & 1.4 & 1.4 & 100.0 \\
\hline $\begin{array}{l}\text { Having proper solid waste reduction } \\
\text { systems that are included in } \\
\text { company policies and procedures }\end{array}$ & $\mathrm{N}$ & 23 & 82 & 20 & 7 & 0 & 8 & 140 \\
\hline $\begin{array}{l}\text { facilitates organizational } \\
\text { sustainability }\end{array}$ & $\%$ & 16.4 & 58.6 & 14.3 & 5.0 & 0.0 & 5.7 & 100.0 \\
\hline $\begin{array}{l}\text { Having a tax policy that ensures } \\
\text { companies are taxed based on the } \\
\text { amount of waste they produce }\end{array}$ & $\mathrm{N}$ & 27 & 52 & 41 & 12 & 4 & 4 & 140 \\
\hline $\begin{array}{l}\text { can help facilitate organizational } \\
\text { sustainability }\end{array}$ & $\%$ & 19.3 & 37.1 & 29.3 & 8.6 & 2.9 & 2.9 & 100.0 \\
\hline Waste reduction can result in & $\mathrm{N}$ & 26 & 63 & 38 & 4 & 5 & 4 & 140 \\
\hline profit maximization and efficiency & $\%$ & 18.6 & 45.0 & 27.1 & 2.9 & 3.6 & 2.9 & 100.0 \\
\hline $\begin{array}{l}\text { Waste reduction is now a concern } \\
\text { for business, manufacturers should }\end{array}$ & $\mathrm{N}$ & 34 & 69 & 21 & 9 & 0 & 7 & 140 \\
\hline $\begin{array}{l}\text { create waste reduction } \\
\text { policies and strategies }\end{array}$ & $\%$ & 24.3 & 49.3 & 15.0 & 6.4 & 0.0 & 5.0 & 100.0 \\
\hline
\end{tabular}

$\mathrm{SA}=$ Strongly agree, $\mathrm{A}=$ Agree, $\mathrm{N}=$ Neutral, $\mathrm{D}=$ Disagree, $\mathrm{SD}=$ Strongly disagree, $\mathrm{NR}=$ No response.

and strongly disagreed, and 4 (2.9\%) did not respond on the same. These findings imply that manufacturing companies in Beni City had adopted solid waste management strategies which could have an impact on organizational sustainability given the significance of the percentages of respondents who agreed and strongly agreed on the related statements. In support of the findings, Chowdlury et al. (2014), noted that reducing waste under inventory control entails purchasing only the amount of raw materials needed for a production run or a set period of time, purchasing the material in the proper amount and the proper size container, approaching the suppliers to see if they can take back the excess materials, and developing review procedures for all materials purchased, to minimize the chances of storing them beyond their shelf-life period.

\subsection{Solid Waste Management Re-Use Strategy}

The second solid waste management strategy that this study sought to establish whether it has been adopted by manufacturing companies in Beni City is re-use strategy. The researcher highlighted various practices of re-use strategy in a manufacturing company and asked respondents to indicate the extent to which they agreed or disagreed that the practices have been adopted in their respective manufacturing company. Findings are as shown in Table 6. 
Table 6. Solid waste management re-use strategy practices adopted by manufacturing companies.

\begin{tabular}{|c|c|c|c|c|c|c|c|c|}
\hline \multicolumn{2}{|l|}{ Re-use strategy practices } & \multirow{2}{*}{$\begin{array}{l}\text { SA } \\
40\end{array}$} & \multirow{2}{*}{ A } & \multirow{2}{*}{$\mathrm{N}$} & \multirow{2}{*}{$\begin{array}{l}\mathrm{D} \\
15\end{array}$} & \multirow{2}{*}{$\begin{array}{c}\mathrm{SD} \\
8\end{array}$} & \multirow{2}{*}{$\frac{\mathrm{NR}}{5}$} & \multirow{2}{*}{$\begin{array}{r}\text { Total } \\
140\end{array}$} \\
\hline $\begin{array}{l}\text { Reusing waste is the best } \\
\text { strategy of creating }\end{array}$ & $\mathrm{N}$ & & & & & & & \\
\hline organizational sustainability & $\%$ & 28.6 & 35.0 & 16.4 & 10.7 & 5.7 & 3.6 & 100.0 \\
\hline $\begin{array}{l}\text { An effective way to reuse solid } \\
\text { waste is through burning } \\
\text { materials that are combustible and }\end{array}$ & $\mathrm{N}$ & 11 & 45 & 34 & 35 & 9 & 6 & 140 \\
\hline $\begin{array}{l}\text { materials through the company's } \\
\text { incinerators }\end{array}$ & $\%$ & 7.9 & 32.1 & 24.3 & 25.0 & 6.4 & 4.3 & 100.0 \\
\hline $\begin{array}{l}\text { Waste ash from incineration } \\
\text { can be used to improve soil }\end{array}$ & $\mathrm{N}$ & 9 & 28 & 52 & 28 & 17 & 6 & 140 \\
\hline fertility on urban areas & $\%$ & 6.4 & 20.0 & 37.1 & 20.0 & 12.1 & 4.3 & 100.0 \\
\hline $\begin{array}{l}\text { Disposal of both non-degradable } \\
\text { and degradable wastes separately }\end{array}$ & $\mathrm{N}$ & 19 & 69 & 30 & 10 & 5 & 7 & 140 \\
\hline $\begin{array}{l}\text { can be used to safely use the } \\
\text { generated wastes for agricultural } \\
\text { purposes }\end{array}$ & $\%$ & 13.6 & 49.3 & 21.4 & 7.1 & 3.6 & 5.0 & 100.0 \\
\hline $\begin{array}{l}\text { Companies can think of new and } \\
\text { better ways of producing and } \\
\text { consuming goods and services to }\end{array}$ & $\mathrm{N}$ & 22 & 79 & 30 & 2 & 0 & 7 & 140 \\
\hline $\begin{array}{l}\text { facilitate the creation of } \\
\text { organizational sustainability }\end{array}$ & $\%$ & 15.7 & 56.4 & 21.4 & 1.4 & 0.0 & 5.0 & 100.0 \\
\hline
\end{tabular}

$\mathrm{SA}=$ Strongly agree, $\mathrm{A}=$ Agree, $\mathrm{N}=$ Neutral, $\mathrm{D}=$ Disagree, $\mathrm{SD}=$ Strongly disagree, $\mathrm{NR}=$ No response.

As shown in Table 6, employees of the manufacturing companies in Beni City gave varied views with regards to the contribution of re-use strategy to organizational sustainability. A total of 89 (63.6\%) of the employees agreed and strongly agreed that re-using waste is the best strategy of creating organizational sustainability while $23(16.4 \%)$ were neutral, 23 (16.4\%) disagreed and strongly disagreed, and 5 (3.6\%) did not respond on the same; 56 (40.8\%) agreed and strongly agreed that an effective way to reuse solid waste is through burning materials that are combustible and melting down non-combustible materials through the company's incinerators while 34 (24.3\%) were neutral, 44 (31.4\%) disagreed and strongly disagreed, and 6 (4.3\%) did not respond on the same; only 37 (26.4\%) agreed and strongly agreed that waste ash from incineration can be used to improve soil fertility on urban areas while $52(37.1 \%)$ were neutral, 45 (32\%) disagreed and strongly disagreed, and $6(4.3 \%)$ did not respond on the same. Further, 88 (62.9\%) of the employees of the manufacturing companies in Beni City agreed and strongly agreed that disposal of both non-degradable and degradable wastes separately can be used to safely use the generated wastes for agricultural purposes while $30(21.4 \%)$ were neutral, 15 (10.7\%) disagreed and strongly disa- 
greed, and 7 (5\%) did not respond on the same. 101 (72.1\%) agreed and strongly agreed that companies can think of new and better ways of producing and consuming goods and services to facilitate the creation of organizational sustainability while $30(21.4 \%)$ were neutral, $2(1.4 \%)$ disagreed, and 7 (5\%) did not respond on the same.

These findings clearly demonstrate that re-use strategy has been adopted by manufacturing companies in Beni City given the significance of percentages where respondents agreed and strongly agreed on the related statements. In accordance, Fernández et al. (2015) [2], noted that reuse by taking, but not reprocessing, previously used items helps save time, money, energy and resources. Fernández et al. also added that many products are then designed to be used more than once.

\subsection{Solid Waste Management Recycling Strategy}

The study sought to establish the extent to which manufacturing companies in Beni City had adopted the recycling strategy in managing their solid waste. Various statements were designed with regards to the practices of recycling strategy in manufacturing companies. Respondents were asked to indicate the extent to which they agreed or disagreed to the statements. Findings are as displayed in Table 7.

From the findings in Table 7, employees of manufacturing companies in Beni City agreed and strongly agreed that recycling can be carried out by companies at waste recycling plants as a strategy of enhancing organizational sustainability at $95(67.9 \%)$ while $20(14.3 \%)$ were neutral, 18 (12.8\%) disagreed and strongly disagreed, and 7 (5\%) did not respond on the same. They also agreed and strongly agreed that recycling mostly depends on the policies that a company has enforced on recycling and also the availability of buyers at 81 (57.9\%) while 43 (30.7\%) were neutral, 7 (5\%) disagreed, and 9 (6.4\%) did not respond on the same. They agreed and strongly that the economy benefits from recycling through reduction of cost of fertilizers since organic waste can easily be transformed into fertilizers at $82(58.6 \%)$ while $43(30.7 \%)$ were neutral, 10 (7.1\%) disagreed and strongly disagreed, and 5 (3.6\%) did not respond on the same; and they agreed and strongly agreed that diversity in recycling leads to creativity in solid waste management strategies at $86(61.4 \%)$ while 35 (25\%) were neutral, 10 (7.1\%) disagree, and $9(6.4 \%)$ did not respond on the same. However, most of the employees of the manufacturing companies at 66 (47.1\%) were not sure that manufacturers of electronic equipment in urban centers are not being given incentives to recycle or buy back electronic waste while 47 (33.6\%) agreed and strongly agreed to the same, $20(14.3 \%)$ disagreed and strongly disagreed, and 7 (5\%) did not respond. Conrad (2000) [12] argues that the materials from which the items are made can be reprocessed into new products. Material for recycling may be collected separately from general waste using dedicated bins and collection vehicles. These findings have shown that recycling strategy had been 
Table 7. Solid waste management recycling strategy practices adopted by manufacturing companies.

\begin{tabular}{|c|c|c|c|c|c|c|c|c|}
\hline Statement & & SA & A & $\mathrm{N}$ & $\mathrm{D}$ & SD & NR & Total \\
\hline $\begin{array}{l}\text { Recycling can be carried out by } \\
\text { companies at waste recycling plants }\end{array}$ & $\mathrm{N}$ & 20 & 75 & 20 & 15 & 3 & 7 & 140 \\
\hline $\begin{array}{l}\text { as a strategy of enhancing } \\
\text { organizational sustainability }\end{array}$ & $\%$ & 14.3 & 53.6 & 14.3 & 10.7 & 2.1 & 5.0 & 100.0 \\
\hline $\begin{array}{l}\text { Recycling mostly depends on the } \\
\text { policies that a company has }\end{array}$ & $\mathrm{N}$ & 14 & 67 & 43 & 7 & 0 & 9 & 140 \\
\hline $\begin{array}{l}\text { enforced on recycling and also the } \\
\text { availability of buyers }\end{array}$ & $\%$ & 10.0 & 47.9 & 30.7 & 5.0 & 0.0 & 6.4 & 100.0 \\
\hline $\begin{array}{l}\text { The economy benefits from recycling } \\
\text { through reduction of cost of }\end{array}$ & $\mathrm{N}$ & 19 & 63 & 43 & 8 & 2 & 5 & 140 \\
\hline $\begin{array}{l}\text { fertilizers since organic waste can } \\
\text { easily be transformed into fertilizers }\end{array}$ & $\%$ & 13.6 & 45.0 & 30.7 & 5.7 & 1.4 & 3.6 & 100.0 \\
\hline $\begin{array}{l}\text { Manufacturers of electronic } \\
\text { equipment in urban centres are not }\end{array}$ & $\mathrm{N}$ & 13 & 34 & 66 & 16 & 4 & 7 & 140 \\
\hline $\begin{array}{l}\text { being given incentives to recycle or } \\
\text { buy back electronic waste }\end{array}$ & $\%$ & 9.3 & 24.3 & 47.1 & 11.4 & 2.9 & 5.0 & 100.0 \\
\hline $\begin{array}{l}\text { Diversity in recycling leads to } \\
\text { creativity in solid waste }\end{array}$ & $\mathrm{N}$ & 27 & 59 & 35 & 10 & 0 & 9 & 140 \\
\hline management strategies & $\%$ & 19.3 & 42.1 & 25.0 & 7.1 & 0.0 & 6.4 & 100.0 \\
\hline
\end{tabular}

$\mathrm{SA}=$ Strongly agree, $\mathrm{A}=$ Agree, $\mathrm{N}=$ Neutral, $\mathrm{D}=$ Disagree, $\mathrm{SD}=$ Strongly disagree, $\mathrm{NR}=$ No response.

adopted by manufacturing companies in managing their solid wastes given the significance of the percentages where the respondents agreed and strongly agreed on the related statements.

\subsection{Inferential Statistics}

The study sought to establish the relationship between the independent variables (solid waste management strategies) and dependent variable (organizational sustainability). The relationship enabled the researcher to make generalizations about the entire population in the solid waste management sector using the sampled population that participated in this study. In order to establish the relationship, regression analysis was conducted to determine the predictive power of independent variables (solid waste management strategies) on the dependent variable (organizational sustainability) using manufacturing companies in solid waste management sector in Beni, DRC.

\subsection{Regression Analysis}

Multiple regression analysis was conducted to test relationship between three solid waste management strategies (the independent variables) and organizational sustainability of companies in solid waste management sector (dependent 
variable). The three solid waste management strategies that the researcher sought to establish their influence on organizational sustainability of companies in solid waste management sector included solid waste reduction strategy, solid waste reuse strategy, and solid waste recycling strategy. The regression analysis coefficients were used in the determination of the relationship between the dependent and the independent variables. The coefficients explain the extent to which changes in the dependent variable can be explained by the change in the independent variables or the percentage of variation in the dependent variable that is explained by all the three independent variables.

\subsubsection{Model Summary}

Table 8 shows the Model Summary of the regression Analysis that was conducted.

From Table 8, findings indicate that the three independent variables (solid waste reduction, solid waste re-use, and solid waste recycling) that were studied explain only $51.3 \%$ (as represented by the Adjusted R Square, $\mathrm{R}^{2}$ ) of the effectiveness of solid waste management strategies on organizational sustainability of manufacturing companies in Beni City, DRC. This therefore means that there are other factors, not studied in this research, that contribute $48.7 \%$ of the effectiveness of solid waste management strategies on organizational sustainability of manufacturing companies in Beni City, DRC. Therefore, further research should be conducted to investigate the other factors (48.7\%) that influence on of the effectiveness of solid waste management strategies on organizational sustainability of manufacturing companies in Beni City, DRC

The findings in Table 8 also show that the F critical at 5\% level of statistical significance is 0.317 . Since the value of F calculated (value $=9.377$ ) is greater than the F critical (value $=0.317$ ), the overall model is considered significant.

\subsubsection{ANOVA Results}

Table 9 shows a summary of the ANOVA statistics obtained from the mean of the three types of solid waste management strategies (reduction, re-use, and recycle) that influence on the effectiveness of solid waste management strategies on organizational sustainability of manufacturing companies in Beni City, DRC. ANOVA cross tabulated results were obtained based on the consideration of average values of respondents' views and opinions on the effectiveness of solid waste management strategies on organizational sustainability of manufacturing

Table 8. Model summary of the regression analysis.

\begin{tabular}{|c|c|c|c|c|c|c|c|c|c|}
\hline \multirow[b]{2}{*}{ Model } & \multirow[b]{2}{*}{$\mathrm{R}$} & \multirow{2}{*}{$\begin{array}{c}\mathrm{R} \\
\text { Square }\end{array}$} & \multirow{2}{*}{$\begin{array}{c}\text { Adjusted } \\
\text { R } \\
\text { Square }\end{array}$} & \multirow{2}{*}{$\begin{array}{l}\text { Std. Error } \\
\text { of the } \\
\text { Estimate }\end{array}$} & \multicolumn{5}{|c|}{ Change Statistics } \\
\hline & & & & & $\begin{array}{l}\text { R Square } \\
\text { Change }\end{array}$ & F Change & df1 & df2 & $\begin{array}{c}\text { Sig. F } \\
\text { Change }\end{array}$ \\
\hline 1 & $0.830^{\mathrm{a}}$ & 0.611 & 0.513 & 0.30499 & 0.611 & 9.377 & 139 & 1 & 0.317 \\
\hline
\end{tabular}

aPredictors: (Constant): solid waste reduction strategy, solid waste reuse strategy, solid waste recycling strategy. 
Table 9. ANOVA of the regression.

\begin{tabular}{cccccc}
\hline \multicolumn{5}{c}{ ANOVA $^{\mathrm{b}}$} \\
\hline Model & Sum of Squares & Df & Mean Square & F & Sig. \\
\hline Regression & 17.895 & 139 & 5.965 & 23.668 & $0.000^{\mathrm{a}}$ \\
Residual & 9.325 & 1 & 0.252 & & \\
Total & 27.220 & 140 & & & \\
\hline
\end{tabular}

bPredictors: (Constant): solid waste reduction strategy, solid waste reuse strategy, solid

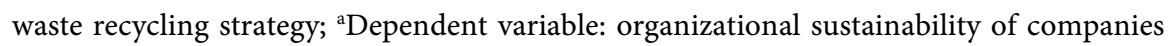
in the manufacturing industry Beni, DRC.

companies in Beni City, DRC. Estimates were made based on the respondents' perception on solid waste reduction strategy, solid waste reuse strategy, solid waste recycling strategy.

The statistical significance value (p) obtained in the regression model is used to measure whether relationship between the independent variables and the dependent variable is statistically significant. From the table above, the significance value for the relationship between solid waste management and organizational sustainability of companies in the manufacturing industry is 0.000 . Since the statistical significance value $(\mathrm{p})$ is less than $0.05(\mathrm{p}<0.05)$, it can be concluded that the relationship between solid waste management and organizational sustainability of companies in the manufacturing industry isstatistically significant in predicting how solid waste management influence organizational sustainability of companies in the manufacturing industry in Beni City.

\subsubsection{Coefficient of Correlation}

The researcher conducted multiple correlation analysis in order to determine the relationship between solid waste management and organizational sustainability of companies in the manufacturing industry in Beni City. The tested variables included: solid waste reduction strategy, solid waste reuse strategy, solid waste recycling strategy. The results were as presented Table 10.

As per the SPSS generated table above, regression equation

$$
Y=\beta_{0}+\beta_{1} X_{1}+\beta_{2} X_{2}+\beta_{3} X_{3}+\varepsilon
$$

where: $Y$ is organizational sustainability of companies in the manufacturing industry as a result of solid waste management strategies

$B_{0}$ is a constant;

$\beta_{1}$ to $\beta_{4}$ are the coefficient of the independent variables;

$X_{1}$ to $X_{3}$ are the independent variables where

$\mathcal{E}$ is the error term.

Therefore,

$$
\begin{aligned}
& Y=\beta_{0}+\beta_{1} X_{1}+\beta_{2} X_{2}+\beta_{3} X_{3}+\varepsilon \text { becomes; } \\
& Y=4.171+0.276 X_{1}+0.264 X_{2}+0.191 X_{3}+\varepsilon
\end{aligned}
$$

From the established equation, it implies that if all the solid waste management strategies employed by manufacturing companies in Beni City are taken 
Table 10. Coefficient of correlation of solid waste management strategies on organizational sustainability in the manufacturing industry.

\begin{tabular}{|c|c|c|c|c|c|c|}
\hline & \multirow{2}{*}{ Model } & \multicolumn{2}{|c|}{$\begin{array}{l}\text { Un-standardized } \\
\text { Coefficients }\end{array}$} & \multirow{2}{*}{$\begin{array}{c}\begin{array}{c}\text { Standardized } \\
\text { Coefficients }\end{array} \\
\text { Beta }\end{array}$} & \multirow{2}{*}{$\begin{array}{c}\mathrm{t} \\
\text { statistics }\end{array}$} & \multirow{2}{*}{$\begin{array}{l}\text { Sig. } \\
\text { Level }\end{array}$} \\
\hline & & $\mathrm{B}$ & Std. Error & & & \\
\hline & (Constant) & 4.171 & 0.644 & & 6.17 & 0.000 \\
\hline 2 & Solid waste reduction strategy & 0.276 & 0.378 & 0.704 & 2.314 & 0.027 \\
\hline 3 & Solid waste reuse strategy & 0.264 & 0.325 & 1.119 & 4.153 & 0.003 \\
\hline 4 & Solid waste recycling strategy & 0.191 & 0.621 & 2.070 & 3.728 & 0.011 \\
\hline
\end{tabular}

aDependent variable: Organizational sustainability in the manufacturing industry.

into account and kept constant at zero, organizational sustainability of manufacturing companies in the manufacturing industry will be at 4.171 . However, the findings in Table 10 indicate that if all other independent variables (solid waste management strategies) are kept constant at zero: a unit increase in solid waste reduction strategy will lead to a $27.6 \%(0.276)$ increase in organization sustainability of manufacturing companies; a unit increase in solid waste reuse strategy will lead to a $26.4 \%(0.264)$ increase in organization sustainability of manufacturing companies; while a unit increase in solid waste recycling strategy will lead to a $19.1 \%(0.191)$ increase in organization sustainability of manufacturing companies.

At 5\% level of statistical significance and $95 \%$ level of confidence, the relationships between solid waste management strategies (solid waste reduction, solid waste re-use, and solid waste recycle) and the organizational sustainability of manufacturing companies in the manufacturing industry were all significant. This is in accordance with Kubanza and Simatele (2016) [7] because the statistical significant value (p) of each solid waste management strategy was less than 0.05 , implying that the relationship of each strategy to organizational sustainability of manufacturing companies in the manufacturing industry was statistically significant.

\section{Conclusion}

The three solid waste management strategies (reduction, re-use, and recycle) explain only $51.3 \%$ of the effectiveness on organizational sustainability of manufacturing companies. However, if all other solid waste management strategies are kept constant at zero: a unit increase in solid waste reduction strategy will lead to a $27.6 \%(0.276)$ increase in organization sustainability of manufacturing companies; a unit increase in solid waste reuse strategy will lead to a $26.4 \%(0.264)$ increase in organization sustainability of manufacturing companies; while a unit increase in solid waste recycling strategy will lead to a $19.1 \%(0.191)$ increase in organization sustainability of manufacturing companies. 


\section{Conflicts of Interest}

The author declares no conflicts of interest.

\section{References}

[1] Hariz, S. and Bahmed, L. (2013) Assessment of Environmental Management System Performance in the Algerian Companies Certified ISO 14001. Management of Environmental Quality: An International Journal, 1, 12-36. https://doi.org/10.1108/14777831311303100

[2] Fernández, J.M.M., Palacios, H.M. and Cabal, J.V.Á. (2015) Methodology for Industrial Solid Waste Management: Implementation to Sludge Management in Asturias (Spain). Journal of Waste Management, 2, 114-129.

[3] UNEP (United Nations Environment Programme) (2013) Guidelines for National Waste Management Strategies: Moving from Challenges to Opportunities. United Nations Institute for Training and Research, Geneva.

[4] Mallak, S.K., Elfghi, F.M., Rajagopal, P., Vaezzadeh, V. and Fallah, M. (2016) Overview of Waste Management Performance of Industrial Sectors by Selected Asian Countries: Current Practices and Issues. International Proceedings of Chemical, Biological and Environmental Engineering, 99, 66-75.

[5] UN-OCHA (United Nations Office for the Coordination of Humanitarian Affairs) (2013) DRC Factsheet Population Movement. United Nations Office for the Coordination of Humanitarian Affairs, Kinshasa.

[6] Mpinda, M.T., Abass, O.K., Bazirake, M.B., Nsokimieno, E.M.M., Mylor, N.S., Kayembe, K.W.M., Khonde, R. (2016) Towards the Efficiency of Municipal Solid Waste Management in the Democratic Republic of Congo (DRC): Case Study of Lubumbashi. American Journal of Environmental Sciences, 12, 193-205. https://doi.org/10.3844/ajessp.2016.193.205

[7] Kubanza, N.S. and Simatele, D. (2016) Social and Environmental Injustices in Solid Waste Management in Sub-Saharan Africa: A Study of Kinshasa, the Democratic Republic of Congo. The International Journal of Justice and Sustainability, 21, 866-882. https://doi.org/10.1080/13549839.2015.1038985

[8] Ndum, A.E. (2013) Bottom-Up Approach to Sustainable Solid Waste Management in African Countries. Brandenburg University of Technology, Cottbus.

[9] Chowdhury, A.H., Mohammad, N., Ul Haque, R. and Hossain, T. (2014) Developing 3Rs (Reduce, Reuse and Recycle) Strategy for Waste Management in the Urban Areas of Bangladesh: Socioeconomic and Climate Adoption Mitigation Option. Journal of Environmental Science, Toxicology and Food Technology, 8, 9-18.

[10] Yousuf, T.B. and Reza, A. (2013) 3R (Reduce, Reuse and Recycle) Action Plan for the City Corporations in Bangladesh: Paradigm Shift of Waste Management to Resource Management. WasteSafe 2013: 3rd International Conference on Solid Waste Management in the Developing Countries, Khulna, 10-12 February 2013, paper ID: 122. https://www.researchgate.net/publication/267762860

[11] Wong, J.W.C., Surampalli, R.Y., Zhang, T.C., Tyagi, R.D. and Selvam, A. (2016) Sustainable Solid Waste Management. American Society of Civil Engineers, Reston. https://doi.org/10.1061/9780784414101

[12] Conrad, K. (2000) A Theory of Production with Waste and Recycling. University of Toronto, Toronto.

[13] Ascher, W. (2000) Applying Classic Organization Theory to Sustainable Resource and Environmental Management. Colloquium on Environmental Law and Institu- 
tions, 5, 92-97.

[14] Hosoda, E. (2014) An Analysis of Sorting and Recycling of Household Waste: A Neo-Ricardian Approach. Metroeconomica, 65, 58-94.

https://doi.org/10.1111/meca.12029

[15] Coopers, P. and Schindler, P. (2008) Business Research Methods. 10th Edition, McGraw Hill. New York.

[16] Mugenda, O. and Mugenda, A. (2003) Research Methods: Quantitative and Qualitative Approaches. African Centre for Technology Studies (ACTS) Press, Nairobi.

[17] Neuman, L.W. (2014) Social research Methods: Qualitative and Quantitative Approaches. 7th Edition, Pearson New International Edition, London.

[18] Hay, C. (2016) Methods That Matter: Integrating Mixed Methods for More Effective Social Science Research. The University of Chicago Press, Chicago.

https://doi.org/10.7208/chicago/9780226328836.001.0001

[19] Sekaran, U. and Bougie, R. (2016) Research Methods for Business. 7th Edition, John Wiley \& Sons Ltd., London.

[20] Choi, H.J. (2016) The Environmental Effectiveness of Solid Waste Management: A Case Study of Oslo, Norway. University of Oslo, Oslo. 